\title{
Red herring vaginal discharge
}

\author{
Jun Hee Lee, ${ }^{1}$ Kirsty Pringle, ${ }^{2}$ Ashok Rajimwale ${ }^{2}$
}

1 Department of Paediatric Surgery, Leicester Royal Infirmary, Leicester, UK ${ }^{2}$ Department of Paediatric Urology, Leicester Royal Infirmary, Leicester, UK

\section{Correspondence to} Dr Jun Hee Lee, jun.lee227@gmail.com
To cite: Lee JH, Pringle K, Rajimwale A. BMJ Case Rep Published online: [please include Day Month Year doi:10.1136/bcr-2013200367

\section{SUMMARY}

Labial hair tourniquet syndrome is a rare condition that can be easily misdiagnosed and ultimately lead to irreversible damage. An 11-year-old premenarche girl presented with a 5-day history of pain and swelling in the labia with associated vaginal discharge. The general practitioner treated her with clotrimazole without improvement. On examination, there was an oedematous swelling of the right labia with a proximal hair tourniquet. Local anaesthetic was applied and the hair removed with forceps. There was instant relief of pain and the discharge stopped within $24 \mathrm{~h}$. The patient was sent home with a course of antibiotics.

\section{DESCRIPTION}

Hair tourniquet syndrome (HTS) is the constriction of a structure with a hair or thread. It usually involves a structure with an end artery such as penis, toes and fingers and less commonly the labia. The constriction from the band disturbs venous and lymphatic return, which can go onto disrupt arterial supply to the structure and cause ischaemia and necrosis, potentially leading to autoamputation. ${ }^{1-3}$ Examination under anaesthesia may be necessary when the diagnosis is not clear or the constricting band is not visible due to the oedematous structure. ${ }^{3}$ In our case, a previously fit and well premenarche 11-year-old girl presented to the hospital with a 5-day history of painful swelling and non-odorous white vaginal discharge 2 days after the onset of pain. There was no history of trauma. She first visited her general practitioner who prescribed clotrimazole for possible candidiasis but it did not help with the symptoms. On examination, the right labia minora was oedematous and significantly larger in size than the left (figure 1). There was a $1 \mathrm{~cm}$ tender pedunculated area of labia distal to what appeared to be a coil of hair the same colour as the patient's hair. She did not have fever and all other observational parameters were stable. Once it was

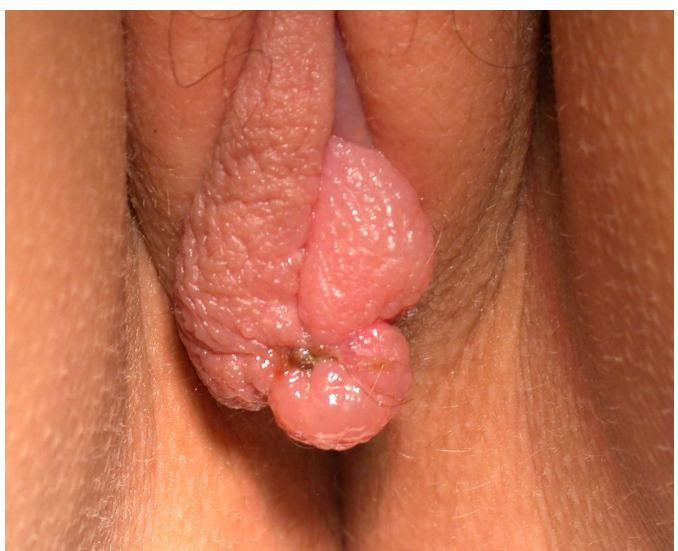

Figure 1 Oedematous right labia minora distal to the coil of hair tourniqueted around the labia. diagnosed as HTS, instillagel was used as local anaesthetic before the hair was removed successfully with forceps, which instantly relieved the pain. The patient was sent home with a 5-day course of oral erythromycin and regular bathing was advised. Follow-up several months later revealed the discharge disappeared within $24 \mathrm{~h}$ after the hair was removed.

\section{Learning points}

Have a high index of suspicion for HTS when a child presents with acute vulvular pain and swelling in order to diagnose and treat early.

- The offending culprit needs to be removed immediately and completely to prevent irreversible damages.

- Follow up patient after several weeks to confirm symptoms have improved to determine if further treatment is warranted.

Contributors JHL admitted and reviewed the patient during on-call shift; took the history and examined the patient; gathered all the information from the patient's notes, made follow-up phone call and conducted the background research and drafted the initial writing and revised it. KP reviewed the patient and diagnosed the condition; took the picture submitted and asked parent for consent about submitting the case to a journal; reviewed and revised the article. AR confirmed the diagnosis of the patient and suggested submitting the patient's case to the journal; reviewed and revised the article and gave final approval for submission.

Competing interests None.

Patient consent Obtained.

Provenance and peer review Not commissioned; externally peer reviewed.

\section{REFERENCES}

1 Barton DJ, Sloan GM, Nichter LS, et al. Hair-thread tourniquet syndrome. Pediatrics 1988:82:925-8.

2 Rich MA, Keating MA. Hair tourniquet syndrome of the clitoris. J Urol 1999;162:190-1.

3 Sivathasan N, Vijayarajan L. Hair-thread tourniquet syndrome: a case report and literature review. Case Rep Med 2012;2012: 171368. http://dx.doi.org/10.1155/2012/171368 
Copyright 2013 BMJ Publishing Group. All rights reserved. For permission to reuse any of this content visit http://group.bmj.com/group/rights-licensing/permissions.

BMJ Case Report Fellows may re-use this article for personal use and teaching without any further permission.

Become a Fellow of BMJ Case Reports today and you can:

- Submit as many cases as you like

- Enjoy fast sympathetic peer review and rapid publication of accepted articles

- Access all the published articles

- Re-use any of the published material for personal use and teaching without further permission

For information on Institutional Fellowships contact consortiasales@bmjgroup.com

Visit casereports.bmj.com for more articles like this and to become a Fellow 